\title{
Иностранная миграция в Республике Бурятия: состояние и проблемы \\ (на примере трудовых мигрантов из ближнего зарубежья)
}

\section{Постановка проблемы}

Миграционные процессы играют значимую роль в социально-экономическом и демографическом развитии Российской Федерации. В Концепции государственной миграционной политики Российской Федерации на период до 2025 года (утв. Президентом РФ от 13 июня 2012 г.) отмечается, что переселение мигрантов на постоянное место жительства в Российскую Федерацию становится одним из источников увеличения численности населения страны в целом и ее регионов, а привлечение иностранных работников по приоритетным профессионально-квалификационным группам в соответствии с потребностями российской экономики является необходимостью для ее дальнейшего поступательного развития [7].

Сегодня внешняя миграция в Российской Федерации создает целый комплекс проблем как для самих мигрантов, так и для принимающего общества. Как отмечает известный российский демографо С.В. Рязанцев, "среди множества проблем, которые стоят в настоящее время перед российской миграционной политикой, пожалуй, самой главной остается адаптация и интеграция мигрантов, прежде всего в части нахождения баланса интересов между местными жителями и мигрантами, приезжающими на жительство в Россию" [14, с. 195].

Республика Бурятия - приграничный регион Российской Федерации, имеющий выгодное географическое положение. Вместе с тем республика находится в самом конце рейтинга социально-экономического положения регионов РФ (69-е место по итогам 2018 г.) Экономист Д.З. Убонова отмечает, что с 2007 г. отставание региона по основным экономическим показателям усилилось. По темпам роста ВРП на душу населения РБ занимает последнее место среди 12 субъектов СФО. Также произошло резкое отставание Бурятии по темпам прироста инвестиций. Сегодня Бурятия входит в число дотационных и депрессивных регионов с низким уровнем и качеством жизни населения. Республика входит в число регионов с самым высоким уровнем безработицы $(9,3 \%)$, который в два раза превышает общероссийский показатель $(4,8 \%)$. Республика Бурятия относится к регионам Российской Федерации, теряющим население, особенно в трудоспособном возрасте [18]. Но миграционные потоки идут также в обратном направлении, когда Бурятия становится регионом-реципиентом, принимающим мигрантов. И здесь возникает множество проблем как для самих мигрантов, так и для принимающего региона. Безусловно, одной из центральных проблем для мигрантов является адаптация в принимающей среде.

Нельзя не отметить, что проблемы внешней миграции являются предметом достаточного количества научных исследований, которые проводят ученые различных специализаций - как социологи, этнологи, так и экономисты. Различные аспекты иностранной миграции в Республику Бурятия изучались

(C) Башкуева Е. Ю., Гунтыпова Э. С., 2020

БАШКУЕВА Елена Юрьевна, канд. ист. наук, научный сотрудник Бурятского научного центра CO PAН (2. Улан-Удэ). E-mail: frombear@mail.ru

ГУНТЫПОВА Эржена Саяновна, канд. социол. наук, заведующая кафедрой связей с общественностью, соџиологии и политологии Бурятской государственной сельскохозяйственной академии им. В.Р. Филиппова (2. Улан-Удэ). E-mail: erzhena-sg@yandex.ru 
Таблица 1. Международная миграция в Республику Бурятия (2013-2018 гг.)

\begin{tabular}{|l|c|c|c|c|c|c|}
\hline & $\mathbf{2 0 1 3}$ & $\mathbf{2 0 1 4}$ & $\mathbf{2 0 1 5}$ & $\mathbf{2 0 1 6}$ & $\mathbf{2 0 1 7}$ & $\mathbf{2 0 1 8}$ \\
\hline Из стран СНГ: в Т.ч. & 434 & 826 & 891 & 811 & 378 & 315 \\
\hline Азербайджан & 46 & 95 & 77 & 75 & 35 & 49 \\
\hline Армения & 64 & 120 & 72 & 83 & 48 & 27 \\
\hline Беларусь & 8 & 6 & 8 & 12 & 6 & 4 \\
\hline Казахстан & 38 & 54 & 35 & 29 & 19 & 12 \\
\hline Киргизия & 72 & 105 & 83 & 95 & 43 & 45 \\
\hline Молдова & 7 & 10 & 9 & 15 & 7 & 4 \\
\hline Таджикистан & 21 & 65 & 72 & 72 & 42 & 59 \\
\hline Туркмения & 3 & 1 & - & 1 & - & 2 \\
\hline Узбекистан & 124 & 226 & 142 & 164 & 45 & 61 \\
\hline Украина & 51 & 144 & 393 & 265 & 133 & 52 \\
\hline Из других зарубежных стран: в Т.ч. & 138 & 193 & 154 & 155 & 54 & 99 \\
\hline КНР & 34 & 72 & 60 & 67 & 22 & 56 \\
\hline Монголия & 47 & 46 & 45 & 37 & 17 & 22 \\
\hline США & 6 & 3 & 1 & 6 & - & 2 \\
\hline Итого & 572 & 1019 & 1045 & 966 & 432 & 414 \\
\hline
\end{tabular}

Источник: составлено на основе [9].

в трудах 3.А. Даниловой и Л.Б.-Ж. Максановой [4], Р.П. Бурдуковского [2], А.В. Саргаева [15], М.М. Содномпиловой и Б.З. Нанзатова [16], Е.А. Шевцовой и А.К. Дмитриевой [20] и др.

Д.Н. Родионова с соавторами в статье "Особенности региональной системы регулирования иностранной трудовой миграции" справедливо отметила, что в Республике Бурятия прослеживается миграционная политика по снижению на рынке труда доли иностранных работников, что является протекционистской мерой в отношении местного населения, испытывающего большие проблемы с трудоустройством [13].

Проблемы адаптации внешних мигрантов и различных её аспектов (правовых, социо-культурных, медико-биологических и др.) в Республике Бурятия рассматривались в работах Н.Ж. Шармашкеевой [19] , Н.Ю. Дылгеровой [5], В.Ю. Башкуева [1], А.В. Саргаева [15] и др.

Так, А.В. Саргаев в своем диссертационном исследовании "Социально-культурная и правовая адаптация иностранных граждан в Российской Федерации (на материалах Республики Бурятия)", анализируя вопросы адаптации иностранных мигрантов в регионе, справедливо отмечает, что первоочередной для мигрантов является потребность в социальной адаптации, решение таких проблем, как поиск работы и жилья. Второй по сложности является правовая адаптация, поскольку основными задачами мигранта являются получение законного статуса и соблюдение всех регистрационных процедур, которые дают мигранту необходимый набор прав, в том числе прав на трудовую деятельность, а также гарантию их защиты. Третьей по сложности мигранты назвали культурную адаптацию [15, с. 21].

Цель предлагаемой статьи - оценка состояния современной иностранной миграции в Республику Бурятия и анализ проблем адаптации мигрантов. В качестве объекта исследования мы выбрали трудовых мигрантов из 
Таблица 2. Миграционная убыль/прирост населения Республики Бурятия (2013-2018гг.)

\begin{tabular}{|l|c|c|c|c|c|c|}
\hline & $\mathbf{2 0 1 3}$ & $\mathbf{2 0 1 4}$ & $\mathbf{2 0 1 5}$ & $\mathbf{2 0 1 6}$ & $\mathbf{2 0 1 7}$ & $\mathbf{2 0 1 8}$ \\
\hline Из стран СНГ: в т.ч. & 370 & 673 & 586 & 450 & -226 & -375 \\
\hline Азербайджан & 37 & 63 & 33 & 39 & -20 & -37 \\
\hline Армения & 56 & 97 & 29 & 44 & -14 & -18 \\
\hline Беларусь & 3 & - & 7 & 5 & - & - \\
\hline Казахстан & 29 & 35 & 12 & -4 & -12 & -15 \\
\hline Киргизия & 68 & 89 & 42 & 51 & -40 & -24 \\
\hline Молдова & 4 & 5 & 6 & 14 & 3 & -2 \\
\hline Таджикистан & 15 & 56 & 63 & 57 & -5 & -5 \\
\hline Туркмения & 3 & 1 & - & -1 & - & 2 \\
\hline Узбекистан & 113 & 203 & 26 & 75 & -86 & -70 \\
\hline Украина & 42 & 124 & 368 & 170 & -52 & -206 \\
\hline Из других зарубежных стран: в т.ч. & 73 & 130 & 83 & 43 & -63 & -40 \\
\hline КНР & 31 & 68 & 43 & 33 & -12 & 15 \\
\hline Монголия & 36 & 36 & 27 & 15 & -10 & -17 \\
\hline США & - & -1 & -5 & -5 & -9 & -4 \\
\hline Итого & 443 & 803 & 669 & 493 & -289 & -415 \\
\hline
\end{tabular}

Источник: составлено на основе [9].

ближнего зарубежья, представителей среднеазиатской и кавказской социально-профессиональных групп, которые численно доминируют в структуре иностранных мигрантов в регионе. Эмпирической базой исследования стали данные официальной статистики - Бурятстата за 2013-2018 годы и ведомственные статистические данные Управления по вопросам миграции Министерства внутренних дел по Республике Бурятия за 2013-2018 годы, а также результаты качественных социологических исследований - экспертного интервью со специалистом агентства "Маяк" и глубинных полуформализованных интервью с трудовыми мигрантами из стран СНГ $(\mathrm{N}=5)$. Мы понимаем, что результаты небольшого по объему социологического исследования не дают возможность делать общие выводы, однако считаем, что они дают представление об основных трудностях, с которыми встречаются иностранные мигранты в Республике Бурятия.

\section{Иностранная миграция в Республику Бурятию} в зеркале официальной и ведомственной статистики

Для выявления основных тенденций иностранной миграции в Республику Бурятия рассмотрим данные официальной и ведомственной статистики.

По данным Бурятстата, в 2013-2018 годах в Республику Бурятия всего прибыло 4448 человек из зарубежных стран, причем большинство - 3655 человек $(82 \%)$ - из стран СНГ. Распределение по годам представлено в $m a$ блице 1. Из стран дальнего зарубежья в Бурятию за 2013-2018 годы прибыло всего 793 человека. Данные статистики показывают, что в 2014-2016 гг. наблюдался рост численности мигрантов в республику почти в два раза.

Общие итоги миграционного обмена с зарубежными странами по данным официальной статистики показывают, что с 2013 по 2016 годы наблю- 
Таблица 3. Цели приезда иностранных граждан в Республику Бурятия (2013-2018гг.)

\begin{tabular}{|l|c|c|c|c|c|c|}
\hline \multicolumn{1}{|c|}{ Цели приезда } & $\mathbf{2 0 1 3}$ & $\mathbf{2 0 1 4}$ & $\mathbf{2 0 1 5}$ & $\mathbf{2 0 1 6}$ & $\mathbf{2 0 1 7}$ & $\mathbf{2 0 1 8}$ \\
\hline \multirow{2}{*}{ Работа по найму } & 1692 & 4723 & 7630 & 11306 & 7674 & 15412 \\
& $(7 \%)$ & $(13 \%)$ & $(25 \%)$ & $(38 \%)$ & $(17 \%)$ & $(33 \%)$ \\
\hline \multirow{2}{*}{ Коммерческая, служебная, деловая } & 2734 & 4305 & 2934 & 3837 & 4419 & 4534 \\
& $(11 \%)$ & $(12 \%)$ & $(9 \%)$ & $(13 \%)$ & $(10 \%)$ & $(10 \%)$ \\
\hline \multirow{2}{*}{ Туризм } & 6362 & 8128 & 2513 & 5357 & 16252 & 17639 \\
& $(26 \%)$ & $(23 \%)$ & $(8 \%)$ & $(18 \%)$ & $(37 \%)$ & $(38 \%)$ \\
\hline \multirow{2}{*}{ Другое } & 13715 & 18657 & 18294 & 9631 & 15794 & 9350 \\
& $(56 \%)$ & $(52 \%)$ & $(58 \%)$ & $(31 \%)$ & $(36 \%)$ & $(19 \%)$ \\
\hline \multirow{2}{*}{ Всего } & 24503 & 35813 & 31371 & 30131 & 44139 & 46935 \\
& $(100 \%)$ & $(100 \%)$ & $(100 \%)$ & $(100 \%)$ & $(100 \%)$ & $(100 \%)$ \\
\hline
\end{tabular}

Источник: составлено на основе [12].

дался миграционный прирост населения, когда число прибывших из других стран превышало число уехавших в эти страны. С 2017 года началась миграционная убыль населения, причем как со странами ближнего, так и дальнего зарубежья (см. табл. 2).

Распределение мигрантов из зарубежных стран по видам деятельности статистическим органом отдельно не производится, поэтому о видах и причинах миграции в Бурятию мы можем узнать из оперативных данных МВД по РБ.

Иммиграционный контроль фиксирует количество прибывших иностранных граждан и лиц без гражданства на территорию РФ, в частности на территорию Республики Бурятия. Всего за 2013-2018 годы Бурятию посетили почти 2 миллиона иностранцев - 1983489 человек. Большинство мигрантов не указывают конкретную цель посещения Бурятии. Данные иммиграционного контроля показывают колебательный характер численности мигрантов, прибывающих в Республику Бурятия с целью работы по найму: в целом за шестилетний период (2013-2018 гг.) число мигрантов возросло в 9 раз с 1692 человек в 2013 году до 15412 человек в 2018 году. Вместе с тем в 2017 году наблюдался спад числа трудовых мигрантов по сравнению с предыдущим годом - 7674 человек в 2017 г. против 11306 человек в 2016 г. Но уже в 2018 году количество мигрантов снова выросло почти в два раза (сл. табл. 3).

Трудовая деятельность иностранных граждан в Российской Федерации осуществляется в двух видах: на основании получения разрешения на работу иностранным гражданам и лицам без гражданства (заявителем выступает работодатель, заказчик работ (услуг), привлекающий иностранных работников, прибывающих на территорию Российской Федерации в порядке, требующем оформления визы) и оформление патента (заявителем выступают законно находящиеся на территории Российской Федерации иностранные граждане и лица без гражданства, прибывшие в Российскую Федерацию в порядке, не требующем получения визы, и достигшие возраста восемнадцати лет).

Трудовые мигранты из "безвизовых" стран на территории Российской Федерации работают по патенту. Патент - это документ, дающий разрешение на осуществление трудовой деятельности в Российской Федерации, но важный нюанс - иностранный гражданин вправе осуществлять трудовую деятельность исключительно в пределах субъекта Российской Федерации, на территории которого ему выдан патент, по указанной в нем профессии (специальности, должности, виду трудовой деятельности). Желающий легально работать в России должен пройти медосмотр, сдать экзамен по русскому языку, истории и праву, оформить полис добровольного медицинского страхования, предоставить нотариально заверенный перевод паспорта, заполнить необходимые анкеты и получить патент. Всем, кто не уложится в 30 дней со дня въезда в Россию, грозит депортация. 
Башкуева Е. Ю., Гунтыпова Э. С. Иностранная миграция в Республике ...

Таблица 4. Выдача патентов иностранным гражданам в Республике Бурятия (2013-2018 гг.)

\begin{tabular}{|l|c|c|c|c|c|c|}
\hline & $\mathbf{2 0 1 3}$ & $\mathbf{2 0 1 4}$ & $\mathbf{2 0 1 5}$ & $\mathbf{2 0 1 6}$ & $\mathbf{2 0 1 7}$ & $\mathbf{2 0 1 8}$ \\
\hline Азербайджан & 363 & 358 & 69 & 95 & 108 & 130 \\
\hline Армения & 425 & 460 & - & - & - & - \\
\hline Киргизия & 1062 & 1034 & 21 & - & - & - \\
\hline Молдова & 14 & 20 & 2 & 1 & 5 & 2 \\
\hline Таджикистан & 435 & 518 & 88 & 174 & 163 & 292 \\
\hline Узбекистан & 5550 & 5070 & 837 & 1471 & 2010 & 2419 \\
\hline Украина & 103 & 96 & 7 & 62 & 34 & 9 \\
\hline Итого & 7952 & 7556 & 1024 & 1803 & 2320 & 2852 \\
\hline
\end{tabular}

Источник: составлено на основе [12].

Освобождены от получения патента граждане государств-членов Евразийского экономического союза - Республика Армения, Республика Беларусь, Республика Казахстан, Киргизская Республика.

Патенты в Республике Бурятия за период с 2013 по 2018 годы оформляли граждане из следующих государств: Азербайджан, Молдова, Таджикистан, Узбекистан, Украина. До 2015 года разрешение на работу также офрормляли граждане Армении и Киргизии. Наибольшее количество патентов было выдано в 2013 году, наименьшее - в 2015 году. Причинами, повлиявшими на сокращение количества приобретения патентов, являются вступление в Евразийский экономический союз Армении и Киргизии, высокая стоимость патента, невысокая правовая культура трудовых мигрантов. В последующие годы наблюдается медленный рост, но количество выданных патентов в 2016-2018 годах не идет в сравнение с 2013-2014 годами, сократившись в среднем более чем в 2 раза (сл. табл. 4).

В количественном отношении ежегодно наибольшее количество патентов в Республике Бурятия оформляли граждане Узбекистана, на втором месте - граждане Таджикистана. В целом же по России на первом месте трудовые мигранты из Узбекистана, на втором - из Украины, а на третьем - из Таджикистана. В Бурятии трудовых мигрантов из Украины немного, за 20132018 годы оформили патенты всего 311 украинских граждан.

Таким образом, статистическая и оперативная информации об иностранных мигрантах в Бурятии за период 2013-2018 годы позволяет определить некоторые тенденции в миграционном обмене с зарубежными странами. Так, наблюдался миграционный прирост с большинством стран ближнего зарубежья в 2013-2014 годы. В 2015-2016 годы отмечается постепенное снижение численности мигрантов из зарубежных стран. А в 2017-2018 годы фриксируется миграционная убыль, когда количество уехавших из Бурятии в эти страны превысило количество приехавших из них в республику. Анализ статистических данных в целом показал, что из стран ближнего зарубежья в Бурятию в основном приезжают граждане Узбекистана, Киргизии, Таджикистана и Азербайджана.

\section{Проблемы адаптации иностранных мигрантов в Республике Бурятия: взгляд эксперта}

Каковы основные трудности адаптации иностранных мигрантов в Республике Бурятия? Каковы ключевые барьеры адаптации в принимающей среде? Для исследования этих вопросов весной 2020 г. авторами было проведено экспертное интервью со специалистом ООО агентство "Маяк".

Нами выделены следующие смысловые блоки интервью: оценка правовой адаптации иностранных мигрантов в Бурятии, анализ адаптации ми- 
грантов с выделением трудностей и барьеров, проблемы социокультурной адаптации мигрантов в регионе.

Эксперт ранее более 15 лет работал в структуре Управления федеральной миграционной службы по Республике Бурятия (ныне - Управление по вопросам миграции МВД РБ) и является сейчас пенсионером МВД. Он отметил, что эта фирма является единственным частным субъектом в г. Улан-Удэ по оказанию помощи иностранным гражданам (лицам без гражданства) в осуществлении миграционного учета, в получении разрешения на временное проживание, в получении вида на жительство, патента, разрешения на работу, в осуществлении регистрационного учета, а также весь спектр бухгалтерских услуг для мигрантов (справки 3-НДФЛ, открытие и ведение ИП, ООО, фотоуслуги). Фирма также помогает в оформлении трудовых договоров, содействует прохождению комплексных медосмотров для мигрантов в медицинских учреждениях.

Эксперт считает, что правовая адаптация является достаточно сложным процессом для любого внешнего мигранта. Это обусловлено сложностью российского миграционного законодательства и его постоянными обновлениями, информационной закрытостью работы миграционных служб, особенно в период пандемии COVID-19. Сам эксперт, прекрасно разбираясь во всех тонкостях миграционного законодательства Российской Федерации, осуществляет помощь мигрантам в самых сложных вопросах - при оформлении документов для разрешения на временное проживания, вида на жительство, российского гражданства. Эксперт отметил, что зачастую только анкеты для получения РВП и вида на жительство приходится исправлять по 5-10 раз. Информант считает, что мигранты очень слабо разбираются в российском миграционном законодательстве и им легче заплатить деньги, чем общаться с чиновниками, многократно подвергать коррекции документы, терять время и испытывать нервное напряжение.

Эксперт отметил, что специалисты миграционных служб из-за большого наплыва иностранных граждан не имеют (по аналогии с медиками) возможности досконально разъяснить все особенности правового статуса мигрантов, поэтому у последних возникает множество вопросов и неясностей. Мигранты из категории образованных обычно сами изучают миграционное законодательство в сети Интернет. Также много полезной информации содержится в сети Интернет на сайте МВД РФ, многочисленных форумах по вопросам миграции. Тем не менее работа таких консультационных центров, как "Маяк", очень востребована в регионе, так как здесь можно быстро и недорого получить квалифищированную помощь в решении многих вопросов, связанных с правовым статусом иностранных граждан.

Относительно проблем адаптации мигрантов в Республике Бурятия, эксперт считает, что они есть и индивидуальны для каждого человека. В целом для граждан ближнего зарубежья, особенно тех, кто родился при СССР, адаптация проходит быстрее и занимает не более 2 лет. Существенную помощь в адаптации оказывают национальные диаспоры и землячества. В Бурятии на государственном уровне выработана грамотная стратегия по содействию адаптации мигрантов - например, в центре г. Улан-Удэ построен "Дом дружбы народов", где мигранты могут встречаться, изучать русский язык, обычаи и традиции как своего, так и русского и бурятского народов. Часто организуются национальные фестивали, концерты, ярмарки. Средства массовой информации охотно рассказывают в положительном контексте о национальных диаспорах. Вместе с тем бывают и негативные моменты, обусловленные недостойным поведением и правонарушениями самих мигрантов.

Рассуждая о трудовой адаптации мигрантов, эксперт считает, что внешним мигрантам удалось "мирно" поделить рынки труда в республике: киргизы в основном занимаются торговлей и сферой услуг, узбеки - общественным питанием и строительно-ремонтными работами, азербайджанцы - торговлей овощами и фруктами и общественным питанием, армяне - строительством дорог и общественным питанием. Китайские мигранты заняты строительством домов, лесозаготовками, общественным питанием. Их нелегальный бизнес в области добычи нефрита правоохранительным органам удалось почти полностью искоренить. Эксперт как положительный факт отметил то, что в целом конфрликтов между иностранными мигрантами и местным населением 
на почве конкуренции на рынках труда в условиях депрессивного развития региональной экономики и высокого уровня безработицы не наблюдалось.

Существенной проблемой для мигрантов является поиск доступного жилья - например, в г. У лан-У дэ достаточно высокие цены на аренду недвижимости. Поэтому обычно мигранты живут целыми кланами в небольших квартирах. Приобрести жилье могут позволить себе лишь высокодоходные группы мигрантов. Ипотеку внешние мигранты офрормляют очень редко.

Относительно языкового барьера эксперт высказался о необходимости разработки методических интерактивных пособий для мигрантов, которыми можно было бы пользоваться самостоятельно, так как подавляющая часть мигрантов - работающие люди, испытывающие недостаток свободного времени. В целом эксперт отметил, что социокультурная адаптация проходит в регионе без особых барьеров, а представители принимающего общества довольно лояльно настроены к мигрантам. По мнению эксперта, региональным властям всё же целесообразно усилить политику по содействию адаптации и

интеграции иностранных мигрантов в республике.

\section{Самооценки адаптации трудовых мигрантов из ближнего зарубежья в Республике Бурятия}

Вопросы адаптации и интеграции иностранных мигрантов в принимающей среде являются наиболее сложными социальными и этнокультурными процессами, которые постоянно изучаются социологами всего мира.

Российский социолог В.Ю. Леденёва рассматривает социальную адаптацию мигрантов как процесс интегративный, вследствие чего достигается баланс взаимоотношений мигранта с социокультурной средой региона, уравновешиваются внешние и внутренние состояния. При успешном развитии процесса социальная адаптации эволюционирует в социальную интеграцию, когда устанавливаются оптимальные связи между относительно самостоятельными социальными объектами, которые в дальнейшем превращаются в единую, целостную систему, состоящую из согласованных и взаимозависимых ее частей на основе общих целей и интересов. Адаптация обоснованно рассматривается в качестве начальной стадии интеграции, но которая может ею и не завершиться [8].

В соответствии с разработанной В.И. Леденёвой стадийной моделью социальной интеграции мигрантов возвратные мигранты (трудовые мигранты) проходят только стадию адаптации. Под критерием адаптации подразумевается способность мигранта бесконфликтно пребывать или проживать, осуществлять трудовую деятельность в новом социуме. При этом иностранец продолжает ощущать особое отношение к себе и к членам своей семьи, как к чужакам, со стороны принимающего общества, сохраняя при этом устойчивые родственные, имущественные и иные связи с прежним местом проживания [8].

Отечественные социологи в разных регионах России фоиксируют рост ксенофобских настроений в отношении иностранных мигрантов, что, безусловно, требует принятия целого комплекса адекватных мер со стороны государства $[3 ; 6 ; 10]$.

Весной 2020 г. нами были проведены глубинные интервью с трудовыми мигрантами из различных социально-профессиональных групп: среднеазиатской (2 узбека) и кавказской (2 азербайджанца и 1 армянин). Были опрошены как низкоквалифицированные, так и высококвалифрицированные мигранты средней возрастной группы, мужского пола. В ходе интервью были выявлены социально-демографические характеристики мигрантов, мотивы и цели миграции, трудности и барьеры адаптации в принимающей среде.

Респондент 1. Валижон - гражданин Узбекистана, уроженец г. Андижан, возраст - 51 год. Около 12 лет проживает в Республике Бурятия, работает отделочником, занимается ремонтом жилых помещений, имеет патент на трудовую деятельность. Русским языком владеет свободно, изучал его еще в школе. По самооценке, он полностью адаптировался к условиям жизни в Бурятии и не испытывает особых трудностей. В первые годы приезда в республику у респондента были проблемы со здоровьем, когда суровой зимой он простудился, и у него было диагностировано заболевание коленного сустава. Однако, 
обратившись в частный медицинский центр, он получил грамотное лечение и быстро поправился. За годы работы благодаря своим профессиональным и личным деловым качествам наработал клиентуру, является востребованным специалистом и не испытывает недостатка в клиентах и финансовых трудностей. Регулярно отсылает деньги на родину, содержит там свою семью. Более того, будучи экономным и неприхотливым в быту, Валижон накопил деньги и вступил в долевое строительство. К сожалению, фирма, которая занималась строительством многоквартирного дома, обанкротилась и в настоящее время он все еще не получил ключи от квартиры, вынужден проживать в съемном жилье, что влечет дополнительные расходы. Внешнее сходство с представителями титульной нации - бурятами - позволяют мигранту смешаться с толпой, и никаких конфликтов с местным населением у Валижона никогда не было. Однако друзей из местного населения он не имеет, старается общаться только с земляками - узбеками, выходцами из г. Андижан. Наш респондент мусульманин, регулярно, особенно на все религиозные праздники, посещает мечеть. Любит и уважает как бурятскую, так и русскую культуры, традиции и обычаи. Например, респондент отметил, что ежегодно отмечает новый год по восточному календарю - национальный бурятский праздник Сагаалган. Любит современное бурятское кино, например, в числе его любимых фрильм "Решала", снятый в 2012 г. Планирует жить и работать в Бурятии, получил вид на жительство в Российской Федеращии. В целом высоко оценил уровень своей адаптащии в принимающей среде, не испытывает никаких трудностей.

Респондент 2. Ислом, гражданин Узбекистана, уроженец г. Коканд, возраст - 51 год. Проживает в Бурятии уже 5 лет, имеет семью на родине, работает в крупной региональной компании, занимающейся строительством дорог. Имеет вид на жительство в РФ. Ислом получил высшее образование по специальности "строительство дорог промышленного транспорта", обучался в советские времена в ВУЗе г. Волгограда. Отметил, что руководство компании ценит его как высокопрофессионального специалиста. В коллективе пользуется уважением, никаких конфликтов с местным населением никогда не было. Работа имеет вахтовый характер (в отдаленных районах Республики Бурятия) и сопряжена с определенными бытовыми трудностями. Ислом тяжело привыкал к суровым климатическим условиям, в первые годы работы постоянно болел простудными заболеваниями, однако в настоящее время полностью привык и чувствует себя комфортно даже при плохой погоде. Имеет много приятелей в среде местного населения. Семья Ислома осталась жить в Узбекистане, и он отправляет половину своей заработной платы на ее содержание. Регулярно общается с семьей и близкими по теледрону и мессенджерам "вайбер" и др. Периодически ездит к себе на родину в отпуск и в связи с семейными событиями (свадьба сына, юбилей жены и т.д.).

Респондент 3. Ильгар, гражданин Азербайджана, уроженец г. Баку, возраст -51 год. Проживает в Бурятии 1 год, холост. Имеет разрешение на временное пребывание в РФ. Приехал в регион по приглашению своего двоюродного брата, который уже давно проживает в России и имеет российское гражданство. Имеет среднее образование. Работает мангальщиком в кафе азербайджанской кухни. Свободно владеет русским языком. Отмечает дружелюбность и толерантность принимающей среды. Совместно со своими земляками арендует небольшую квартиру. Респондент считает, что в регионе необоснованно высокие цены на аренду жилья и найти подходящий вариант достаточно сложно. Кроме того, не все собственники жилья хотят сдавать его именно мигрантам, опасаясь проблем с правоохранительными органами. Информант отметил, что в адаптации ему помогли родственники и представители действующей региональной общественной организации "Национально-культурная Автономия Азербайджанцев Республики Бурятия". Друзей среди местного населения не имеет, в основном общается с земляками-азербайджанцами. В планах Ильгара жениться на местной женщине, приобрести квартиру, получить гражданство Российской Федерации, полностью адаптироваться к местной жизни.

Респондент 4. Халид, уроженец г. Гянджа (Азербайджан), 44 года. Проживает в столице Бурятии г. Улан-У дэ уже 7 лет, женат. В 2019 г. получил российское гражданство. Получил высшее образование по специальности "менеджмент". Имеет стабильный и прибыльный бизнес - сеть пави- 
льонов с овощной и фрруктовой продукцией. Организовал интернет-магазин в г. Улан-Удэ по доставке свежих фрруктов из Таиланда, наработал сеть постоянных клиентов.

Высокие доходы от бизнеса позволили ему приобрести комфортабельную благоустроенную квартиру. Весной 2020 г., в период разгара пандемии COVID-19 и ограничительных мер, Халид развернул благотворительную доставку фрруктов инвалидам и малоимущим, что широко освещалось в СМИ как на региональном, так и на федеральном уровнях. Правительство Республики Бурятия поощрило его благодарственным письмом. Руководство диаспоры также поблагодарило бизнесмена за активную благотворительную деятельность. Наш информант свободно говорит по-русски и знает базовые слова на бурятском языке. Имеет много друзей и бизнес-партнеров как русской, так и бурятской национальности. Активно пользуется социальными сетями, имеет много подписчиков и часто рекламирует свой товар в социальных сетях. Респондент отметил, что с момента приезда в Бурятию, не испытывал особых трудностей в адаптации. Тяжело было привыкать к резко-континентальному климату, но молодой организм мигранта быстро закалился. Сейчас Халид является активным членом местной региональной общественной организации "Национально-культурная Автономия Азербайджанцев Республики Бурятия", сам помогает многим своим соотечественникам с адаптацией в регионе.

Респондент 5. Артак, гражданин Армении, уроженец г. Спитак, возраст 38 лет. Разведен. Имеет среднее образование. Проживает в Бурятии 3 года, работает в области дорожного строительства машинистом асфальтового катка. Имеет вид на жительство в РФ. Проживает совместно со своими родственниками в арендуемой квартире. По-русски говорит свободно. Имеет много друзей и знакомых среди местного населения. Планирует приобрести квартиру в г. Улан-Удэ, копит на это деньги. Хотел бы жениться на соотечественнице - армянке, которая тоже проживает в Бурятии. Отметил, что его адаптация прошла спокойно, он привык к Бурятии и ему нравится здесь всё: природа, люди, культура. Отметил, что есть трудности во взаимодействии с миграционными службами (трудно дозвониться и попасть на консультацию, большие очереди), однако они решаемы.

Таким образом, обобщая полученные в ходе глубинных интервью сведения, мы пришли к следующим выводам. Нами были опрошены представители только мужского пола, однако это позволило выявить важную гендерную специфику трудовой миграции - приезд в Бурятию был обусловлен собственными желаниями и целями мужчин. Основной мотив приезда - экономический, направленный на улучшение материального благосостояния. Опрошенные нами мигранты не столкнулись с проблемой поиска работы и дискриминацией на рынке труда, несмотря на высокий уровень безработицы в регионе. Все респонденты свободно владеют русским языком. Достаточно сложно у них прошла адаптация к суровым климатическим условиям республики. Существенной проблемой является поиск доступного жилья, но, если у мигрантов есть на это средства, они приобретают благоустроенные квартиры. Есть определенные проблемы с правовой адаптацией и взаимодействием с миграционным службами. Социокультурная адаптация у опрошенных мигрантов проходит хорошо. Национальные объединения мигрантов оказывают им поддержку и являются ключевыми акторами политики адаптации и интеграции мигрантов в регионе.

На наш взгляд, опрошенные представители среднеазиатской и кавказской социально-профессиональных групп демонстрируют и успешно реализовывают свой высокий адаптивный потенциал, несмотря на обозначенные трудности и проблемы в их новой жизни в Бурятии.

\section{Заключение}

Таким образом, проведенное нами исследование позволяет сделать следующие выводы.

Основными миграционными донорами Республики Бурятия являются государства Средней Азии и Закавказья: Узбекистан, Киргизия, Таджикистан и Азербайджан. В количественном измерении, в 2013-2014 годы наблюдался миграционный прирост с большинством стран ближнего зарубежья. В 
2015-2016 годы зафиксировано постепенное снижение численности мигрантов из зарубежных стран. В 2017-2018 годы выявлена миграционная убыль, когда количество уехавших из Бурятии в эти страны превысило количество приехавших из них в республику.

По данным экспертного интервью с сотрудником фрирмы "Маяк", которая оказывает консультационные услуги для иностранных мигрантов, основной проблемой, связанной с пребыванием данного контингента, является оформление разрешительных документов и сложное российское миграционное законодательство. Эксперт отметил низкий уровень правовых знаний иностранных мигрантов, что влечет большие трудности в оформлении разрешительных документов.

Отдельной проблемой является адаптация иностранных мигрантов в принимающей среде. Эксперт отметил, что выходџы из ближнего зарубежья в среднем адаптируются в течение 2 лет. В целом информанты из Узбекистана, Азербайджана и Армении отметили, что не испытывают серьезных трудностей с адаптацией, чувствуют себя в Бурятии востребованными специалистами, не испытывают дискриминации на рынке труда и считают, что данный регион достаточно безопасен и комфортен для проживания. Не встречались они и с негативным отношением со стороны представителей принимающего общества. Определенные трудности адаптации были обусловлены суровыми климатическими условиями региона, дороговизной аренды жилья. Национальные объединения активно помогают мигрантам в адаптации.

На наш взгляд, наиболее подходящей стратегией адаптации мигрантов в принимающей среде должна стать гармоничная интеграция. С этой целью следует усилить процесс взаимодействия органов государственного управления, курирующих вопросы внешней миграции, социальных служб, общественных объединений, национальных диаспор, землячеств.

Ситуация с пандемией коронавируса COVID-19, безусловно, внесет огромные социально-экономические изменения, в том числе в миграционной картине на всех континентах, не останется исключением и Республика Бурятия. Однако международная миграция останется при любом раскладе важнейшим аспектом социально-экономического развития территорий в условиях глобализации.

\section{Литература}

1. Башкуев В.Ю. Современные особенности медико-биологической адаптации монгольских и киргизских мигрантов в Республике Бурятия // Власть. 2015. № 11. C. $142-147$.

2. Бурдуковский Р.П. Сравнительный анализ миграционных процессов Республики Бурятия в условиях несбалансированного рынка труда// Вестник ТГЭУ. № 3. 2013. C. 68-78.

3. Винокурова А.В., Ардальянова А.Ю. Этноконфессиональные аспекты социальной адаптации трудовых мигрантов в Приморском крае // Дискурс. 2017. № 12 (14). C. $134-141$.

4. Данилова З.А., Максанова Л.Б.-Ж. Зарубежная миграция как источник трудовых ресурсов Байкальского региона // Вестник Бурятского государственного университета. Экономика и менеджмент. 2019. №3. С. 35-39.

5. Дылгерова Н.Ю. Исследование социокультурной адаптации трудовых мигрантов из Украины в Бурятию // Вестник науки и образования Северо-Запада России. 2015. № 4. Т. 1. С. 1-5.

6. Константинов А.В., Дульнев М.В. Миграционный кодекс Российской Федерации как результат систематизации миграционного законодательства// Вестник Московского университета МВД России. 2019. № 2. С. 204-207.

7. Концепция государственной миграционной политики Российской Федерации на период до 2025 года (утв. Президентом РФ от 13 июня 2012 г.) // Справочно-правовая система "Гарант" (дата обращения: 12.05.2020).

8. Леденёва В.Ю. Модели социальной адаптации и интеграции трудовых мигрантов: монография. М.: Изд-во "Спутник +", 2014. 144 с.

9. Международная миграция в Республику Бурятия. [Электронный ресурс]. URL: https://burstat.gks.ru/demo (дата обращения: 01.04.2020).

10. Мукомель В.И. Адаптация и интеграция мигрантов: методологические подходы к оценке результативности и роль принимающего общества // Россия реформирующаяся. 2016. № 14. С. 411-467. 
11. Панкратьев А.А. Внешняя трудовая миграция как фрактор достижения сбалансированности рынка труда территории: Автореферат дис. кандидата экон. наук. Воронеж, 2020. 24 с.

12. Письмо Управления по вопросам миграции Министерства внутренних дел по Республике Бурятия от 15.05.2019 № 4716228.

13. Родионова Д.Н., Хайхадаева О.Д., Дугаров А.А. Особенности региональной системы регулирования иностранной трудовой миграции // Вестник Бурятского государственного университета. Экономика и менеджмент. 2020. № 1. С. 40-54.

14. Рязанцев С.В. Адаптация и интеграция трудовых мигрантов в российское общество: социокультурные риски и подходы к стимулированию // Демографический и миграционный потрет Казказа. Серия "Демография. Социология. Экономика". Под редакцией С.В. Рязанцева, Г.И. Гаджимурадовой. Москва, 2019. С. 195-201.

15. Саргаев А.В. Социально-культурная и правовая адаптация иностранных граждан в Российской Федерации (на материалах Республики Бурятия): Авторедерат дис. кандидата социол. наук. Улан-Удэ, 2015. 24 с.

16. Содномпилова М.M., Нанзатов Б.З. Миграционные процессы XXI в. в постсоветском пространстве: традиция как выталкивающий фрактор// Вестник Бурятского государственного университета. 2013. № 1. С. 98-106.

17. Трофименко А.В., Шмелева О.В. Проблемы определения правового положения иностранных граждан в Российской Федерации // Наука и общество. 2019. № 1 (33). C. $114-119$.

18. Убонова Д.З. Сравнительный анализ экономического развития Республики Бурятия и субъектов Сибирского Федерального Округа // Вестник БНЦ СО РАН. 2019. № 1 (33). C. 192-197.

19. Шармашкеева Н.Ж. Социокультурная адаптация китайских мигрантов в Бурятии: Авторедерат дис. кандидата истор. наук. Москва, 2007. 24 с.

20. Шевцова Е.А., Дмитриева А.К. Миграционная политика Республики Бурятия: сценарные подходы // Вестник Тюменского государственного университета. Социально-экономические и правовые исследования. 2016. Т. 2. № 2. С. 59-71.

\section{Транслитерация по ГОСТ 7.79-2000 Система Б}

1. Bashkuev V.YU. Sovremennye osobennosti mediko-biologicheskoj adaptatsii mongol'skikh i kirgizskikh migrantov v Respublike Buryatiya // Vlast'. 2015. № 11. S. 142147.

2. Burdukovskij R.P. Sravnitel'nyj analiz migratsionnykh protsessov Respubliki Buryatiya v usloviyakh nesbalansirovannogo rynka truda// Vestnik TGEHU. № 3. 2013. S. $68-78$.

3. Vinokurova A.V., Ardal'yanova A.YU. EHtnokonfessional'nye aspekty sotsial'noj adaptatsii trudovykh migrantov v Primorskom krae // Diskurs. 2017. № 12 (14). S. 134141.

4. Danilova Z.A., Maksanova L.B.-ZH. Zarubezhnaya migratsiya kak istochnik trudovykh resursov Bajkal'skogo regiona // Vestnik Buryatskogo gosudarstvennogo universiteta. EHkonomika i menedzhment. 2019. № 3. S. 35-39.

5. Dylgerova N.YU. Issledovanie sotsiokul'turnoj adaptatsii trudovykh migrantov iz Ukrainy v Buryatiyu // Vestnik nauki i obrazovaniya Severo-Zapada Rossii. 2015. № 4. T. 1. S. $1-5$.

6. Konstantinov A.V., Dul'nev M.V. Migratsionnyj kodeks Rossijskoj Federatsii kak rezul'tat sistematizatsii migratsionnogo zakonodatel'stva// Vestnik Moskovskogo universiteta MVD Rossii. 2019. № 2. S. 204-207.

7. Kontseptsiya gosudarstvennoj migratsionnoj politiki Rossijskoj Federatsii na period do 2025 goda (utv. Prezidentom RF ot 13 iyunya 2012 g.) // Spravochno-pravovaya sistema "Garant" (data obrashheniya: 12.05.2020).

8. Ledenyova V.YU. Modeli sotsial'noj adaptatsii i integratsii trudovykh migrantov: monografiya. M.: Izd-vo "Sputnik +", 2014. 144 s.

9. Mezhdunarodnaya migratsiya v Respubliku Buryatiya. [EHlektronnyj resurs]. URL: https://burstat.gks.ru/demo (data obrashheniya: 01.04.2020).

10. Mukomel' V.I. Adaptatsiya i integratsiya migrantov: metodologicheskie podkhody k otsenke rezul'tativnosti i rol' prinimayushhego obshhestva // Rossiya reformiruyushhayasya. 2016. № 14. S. 411-467.

11. Pankrat'ev A.A. Vneshnyaya trudovaya migratsiya kak faktor dostizheniya sbalansirovannosti rynka truda territorii: Avtoreferat dis. kandidata ehkon. nauk. Voronezh, 2020. $24 \mathrm{~s}$

12. Pis'mo Upravleniya po voprosam migratsii Ministerstva vnutrennikh del po Respublike Buryatiya ot 15.05.2019 № 4716228 .

13. Rodionova D.N., KHajkhadaeva O.D., Dugarov A.A. Osobennosti regional'noj sistemy regulirovaniya inostrannoj trudovoj migratsii // Vestnik Buryatskogo gosudarstvennogo universiteta. EHkonomika i menedzhment. 2020. № 1. S. 40-54. 
14. Ryazantsev S.V. Adaptatsiya i integratsiya trudovykh migrantov v rossijskoe obshhestvo: sotsiokul'turnye riski i podkhody k stimulirovaniyu // Demograficheskij i migratsionnyj potret Kazkaza. Seriya "Demografiya. Sotsiologiya. EHkonomika". Pod redaktsiej S.V. Ryazantseva, G.I. Gadzhimuradovoj. Moskva, 2019. S. 195-201.

15. Sargaev A.V. Sotsial'no-kul'turnaya i pravovaya adaptatsiya inostrannykh grazhdan v Rossijskoj Federatsii (na materialakh Respubliki Buryatiya): Avtoreferat dis. kandidata sotsiol. nauk. Ulan-Udeh, 2015. $24 \mathrm{~s}$.

16. Sodnompilova M.M., Nanzatov B.Z. Migratsionnye protsessy XXI v. v postsovetskom prostranstve: traditsiya kak vytalkivayushhij faktor// Vestnik Buryatskogo gosudarstvennogo universiteta. 2013. № 1. S. 98-106.

17. Trofimenko A.V., SHmeleva O.V. Problemy opredeleniya pravovogo polozheniya inostrannykh grazhdan v Rossijskoj Federatsii // Nauka i obshhestvo. 2019. № 1 (33). S. $114-119$

18. Ubonova D.Z. Sravnitel'nyj analiz ehkonomicheskogo razvitiya Respubliki Buryatiya i sub"ektov Sibirskogo Federal'nogo Okruga // Vestnik BNTS SO RAN. 2019. № 1 (33). S. 192-197.

19. SHarmashkeeva N.ZH. Sotsiokul'turnaya adaptatsiya kitajskikh migrantov v Buryatii: Avtoreferat dis. kandidata istor. nauk. Moskva, 2007. 24 s.

20. SHevtsova E.A., Dmitrieva A.K. Migratsionnaya politika Respubliki Buryatiya: stsenarnye podkhody // Vestnik Tyumenskogo gosudarstvennogo universiteta. Sotsial'no-ehkonomicheskie i pravovye issledovaniya. 2016. T. 2. № 2. S. 59-71.

Башкуева Е. Ю., Гунтыпова Э. С. Иностранная миграция в Республике Бурятия: состояние и проблемы (на примере трудовых мигрантов из ближнего зарубежья).

В статье представлен анализ современной иностранной миграции в Республику Бурятия. На основе анализа данных официальной статистики (Бурятстат) и оперативных ведомственных данных Управления по вопросам миграции Министерства внутренних дел по Республике Бурятия за 2013-2018 гг. выявлены особенности миграционных потоков в Республику Бурятия. На основе качественного социологического исследования (әкспертного интервью со специалистом консалтинговой формы "Маяк", глубинных интервью с трудовыми мигрантами из ближнего зарубежья) установлены преимущества и трудности в адаптации иностранных мигрантов в Республике Бурятия.

Ключевые слова: иностранные граждане, иностранная миграция, мигранты, ближнее зарубежье, патент, адаптаиия, Республика Бурятия

Bashkueva E. YU., Guntypova EH. S. Foreign migration in the Republic of Buryatia: state and problems (on the example of labor migrants from neighboring countries).

The article presents an analysis of modern foreign migration to the Republic of Buryatia. Based on the analysis of official statistics (Buryatstat) and operational departmental data of the Migration Department of the Ministry of Internal Affairs for the Republic of Buryatia for 2013-2018. the features of migration flows to the Republic of Buryatia are revealed. On the basis of a qualitative sociological study (an expert interview with a specialist of the consulting firm "Mayak", in-depth interviews with labor migrants from the near abroad), the advantages and difficulties in the adaptation of foreign migrants in the Republic of Buryatia were established.

Key words: foreign citizens, foreign migration, migrants, neighboring countries, patent, adaptation, Republic of Buryatia

Для цитирования: Башкуева Е. Ю., Гунтыпова Э. С. Иностранная миграция в Республике Бурятия: состояние и проблемы (на примере трудовых мигрантов из ближнего зарубежья) // Ойкумена. Регионоведческие исследования. 2020. № 4. C. 71-82. DOI: 10.24866/1998$6785 / 2020-4 / 71-82$

For citation: Bashkueva E. YU., Guntypova EH. S. Foreign migration in the Republic of Buryatia: state and problems (on the example of labor migrants from neighboring countries) // Ojkumena. Regional researches. 2020. № 4. P. 71-82. DOI: $10.24866 / 1998-6785 / 2020-4 / 71$ 82 